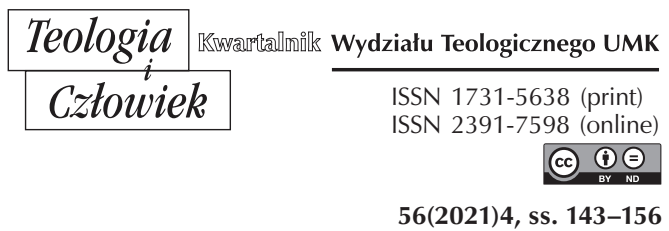

REV. JANUSZ SZULIST

NICOLAUS COPERNICUS UNIVERSITY IN TORUŃ

SZULIST@UMK.PL

ORCID 0000-0002-0410-0565

\title{
REALISM OF POLITICAL ACTIVITY IN THE TEACHING OF POPE FRANCIS
}

DOI: http://dx.doi.org/10.12775/TiCz.2021.032

\begin{abstract}
This paper presents an argument for political realism in response to the trends of populism and liberalism. Pope Francis emphasizes the need to restore a social order whose functioning would be judged from the perspective of the common good. The human person holds an overriding social value that is not subject to the laws of exchange. This unique status justifies selflessness of action as a long-term measure aimed at restoring social equity. In that context, education as a process of the formation of personality becomes synonymous with the process of humanization of the world, where the human person is increasingly conscious of his or her subjectivity. Conversely, the ideologies of populism and liberalism and the resulting systems aim to objectify the individual by catering to the lowest instincts and seeking immediate benefits. In his political reflection, Pope Francis draws directly from his encyclical letter Laudato si, and thus - indirectly from the constitution Gaudium et Spes.
\end{abstract}

Keywords: politics, realism, Francis, common good, sacrifice, populism, liberalism.

Streszczenie. Realizm działalności politycznej w nauczaniu papieża Franciszka. Artykuł prezentuje postulat realizmu politycznego w obliczu trendów populizmu oraz liberalizmu. Papież Franciszek podkreśla konieczność przywrócenia porządku społecznego, którego działanie będzie oceniane z perspektywy dobra wspólnego. Osoba stanowi nadrzędną wartość społeczną niepodlegającą prawom wymiany. Ów wyjątkowy status człowieka uzasadnia bezinteresowność w działaniach jako długofalowy środek mający na celu przywrócenie sprawiedliwości społecznej. Wychowanie, będące formą kształtowania 
osobowości, jest w tym układzie tożsame z procesem humanizacji świata, gdzie człowiek jest coraz bardziej świadomy swojej podmiotowości. Ideologie populizmu i liberalizmu stanowią tymczasem systemy zmierzające do uprzedmiotowienia jednostki, przy odwołaniu się do najniższych instynktów oraz doraźnych korzyści. W refleksji politycznej papież Franciszek nawiązuje bezpośrednio do swojej encykliki Laudato si, a w dalszej perspektywie do konstytucji Gaudium et spes.

Słowa kluczowe: polityka, realizm, Franciszek, dobro wspólne, ofiarność, populizm, liberalizm.

Political activity serves to satisfy the demands of the common good. ${ }^{1}$ The broad understanding of politics that prevails in the Catholic social doctrine also encompasses the meaning that applies when politics is understood as the struggle for power. ${ }^{2}$ In any sense of the word, politics involves individual or collaborative efforts aimed at advancing development in accordance with a previously adopted agenda or within the framework of a specific ideology. ${ }^{3}$ Political activity is the object of reflection not only in political science, ${ }^{4}$ political sociology ${ }^{5}$ and related fields, but also in theology, and above all, in moral theology, which interprets human acts in the light of the revelation and, at the same time, in reference to specific social circumstances. ${ }^{6}$ Pope Francis points to politics as a form of activity pursued by a human person who is naturally oriented towards the realization of specific values and capable of acting according to principles. The purpose of such acts is to seek justification, to use Saint Paul's terminology, ${ }^{7}$ whereas in the earthly life, a process of formation of personality takes place in the context of the objective moral order

1 Cf. Second Vatican Council, Pastoral Constitution on the Church in the Modern World: Gaudium et spes, Vatican City 1965, sec. 26 (hereafter cited as GS).

2 Cf. J. Szulist, "Człowiek jest droga Kościoła" (RH 14). Wprowadzenie do katolickiej nauki społecznej, Pelplin 2012, pp. 112-113.

3 Cf. J. Szulist, Teologia państwa w pismach Josepha Ratzingera (Benedykta XVI), Toruń 2016, p. 65.

${ }^{4}$ Cf. J. Potulski, "Problem 'tego co polityczne’ a tożsamość badawcza politologii," Annales Universitatis Mariae Curie-Skłodowska XXIII (2016) 2, p. 66.

${ }^{5}$ Cf. J. J. Wiatr, Socjologia polityki, Warsaw 2009, p. 120.

${ }^{6}$ Cf. S. T. Pinckaers, Źródła moralności chrześcijańskiej, Poznań 1994, pp. 29-30.

7 Cf. ibid., pp. 127-128. 
founded on love that originates from God. ${ }^{8}$ As has been noted, the pope's teaching on politics is a certain continuation of the reflection contained in Laudato si, his first social encyclical letter. ${ }^{9}$

\section{TRENDS THAT DISTORT THE VISION OF SOCIETY}

In the pope's social teaching, there are quite frequent references to certain trends in the society that distort the perception of social phenomena and, as a result, cause ever-deepening social injustice, ${ }^{10}$ which then translates into the exclusion of individuals and groups or a significant reduction of their influence on the policies being pursued in the sense of an ever fuller realization of the demands of the common good. ${ }^{11}$ In this context, Marxism has been identified on many occasions as a doctrine that directly conflicts with the natural considerations of an individual as regards, for example, spiritual life. ${ }^{12}$ In his encyclical letter Fratelli tutti, Pope Francis underlines the importance of two other social trends which nowadays result in a reductionist concept of the human being, and in effect, a fragmentary vision of politics - which, after all, should by definition foster integral development in the individual and collective dimensions. ${ }^{13}$ The first of the social trends noted by the pope is populism. ${ }^{14}$ Etymologically, the word "populism" stems from the Latin populus, which is translated as

${ }^{8}$ Cf. Benedict XVI, Deus caritas est, encyclical letter, Vatican City 2005, sec. 1 (hereafter cited as DCE).

9 Cf. Francis, Laudato si, encyclical letter, Vatican City 2015, secs. 176-181 (hereafter cited as $L S i)$.

10 Cf. Francis, General Audience of 9 October 2019, https://www.vatican.va/ content/francesco/en/audiences/2019/documents/papa-francesco_20191009_udienzagenerale.html.

11 Cf. GS, sec. 26.

12 Cf. John Paul II, Laborem exercens, encyclical letter, Vatican City 1981, sec. 11 (hereafter cited as $L E$ ); M. M. Bużyk, "Problematyka filozoficznych podstaw pedagogiki w sporze Wydziału Filozofii Chrześcijańskiej KUL z marksizmem,” Polska Myśl Pedagogiczna 3 (2017), pp. 70-71.

13 Cf. Francis, Fratelli tutti, encyclical letter, Vatican City 2020, secs. 154-155 (hereafter cited as FT).

14 Cf. S. Olszyk, "'Vox populi, vox Dei': teoria populizmu politycznego," Annales Universitatis Paedagogicae Cracoviensis. Studia Politologica 3 (2007), pp. 236-237. 
"the people." 15 The promotion of populism is closely associated with a political calculation to gain power, whereby elements of national identity are instrumentalized or certain social factors are absolutized (typically those unfavorable or unfair to a particular social group). ${ }^{16}$ In his description of the phenomenon of populism, Pope Francis refers to the distinctions of populism typical of political science or political philosophy: [block] The service [the popular leaders] provide [...] can degenerate into an unhealthy "populism" when individuals are able to exploit politically a people's culture, under whatever ideological banner, for their own personal advantage or continuing grip on power. Or when, at other times, they seek popularity by appealing to the basest and most selfish inclinations of certain sectors of the population. This becomes all the more serious when, whether in cruder or more subtle forms, it leads to the usurpation of institutions and laws. ${ }^{17}$ In the view of Pope Francis, a characteristic feature of populism is that it makes the nation a closed group - completely subordinated to the interests of its leader or the political party which is currently in power. ${ }^{18}$ Populists intentionally choose certain elements of the nation's identity that have a particular impact on the emotional responses of broader social groups. ${ }^{19}$ Thus, wrongs incurred from those more powerful or events of triumph are recalled, the greatest effectiveness is attributed to the broad mobilization of the society, and so on. ${ }^{20}$ Any new factors or interpretations based on objective criteria are typically regarded by populists as threats ${ }^{21}$ to such values as liberty, personal sense of dignity, social subjectivity, etc. ${ }^{22}$ Another characteristic of populism noted by Pope Francis is the short-term nature of the activities being undertaken. Populist politicians call for solutions which would enable them to gain power or retain it for subsequent terms within a short period of time (preferably

15 Cf. J. Pakulski, "Ruchy populistyczne i degeneracja elit przywódczych - analiza weberowska," Zoon Politiko 7 (2016), p. 58.

16 Cf. R. Tokarczyk, Wspótczesne doktryny polityczne, Warsaw 2010, p. 505.

17 FT, sec. 159.

${ }^{18}$ Cf. ibid., sec. 160.

19 Cf. S. Olszyk, "'Vox populi,” p. 238.

20 Cf. J. Pakulski, “Ruchy populistyczne," pp. 59-60.

${ }^{21}$ Cf. S. Olszyk, "Vox populi," p. 238.

${ }^{22}$ Cf. J. Pakulski, "Ruchy populistyczne," p. 60. 
at once). ${ }^{23}$ Temporary forms of assistance undermine the sense of security and directly preclude the long-term development that goes hand in hand with an individual's activity in the world. ${ }^{24}$

Another social trend that contributes to the derealization of political activity and deepens social divisions is liberalism, whose negative effects were already brought to light in the early Catholic social doctrine. ${ }^{25}$ Pope Francis points to the individualism that characterizes the modern "liberal approaches." 26 In studies on political doctrines, individualism is considered one of the principal ideas of liberalism. ${ }^{27}$ Its main tenet is that an individual is free and self-sufficient in his or her manner of being and achieves all goals independently. Thus, individualism can be equated with subjectivism, absolute activism and unlimited individual agency. ${ }^{28}$ In a culture of individualism, the human ego is not subordinated to anyone or anything - neither to other people nor to social institutions. ${ }^{29}$ All relations with others - which enhance individual life - take place within the social contract, ${ }^{30}$ a concept which has been extensively promoted since the Enlightenment. ${ }^{31}$ Liberal views with an individualistic profile - even if one assumes that they are based on the uniqueness of a human being as an individual in the social order - render political action ineffective. State aid reaches few people and therefore fails to stimulate social bonds at the level of, for instance, the family or the nation: "At times, [...] leftist ideologies or social doctrines linked to individualistic ways of acting and ineffective procedures affect only a few, while the majority of those left behind remain dependent on the goodwill of others." 32 The adverse effects of individualistic practices are further exacerbated by the coexistence of any

${ }^{23}$ Cf. FT, sec. 162.

${ }^{24}$ Cf. Benedict XVI, Caritas in veritate, encyclical letter, Vatican City 2009, sec. 68 (hereafter cited as $C V$ ).

25 Por. I. Mroczkowski, “Liberalizm. Aspekt teologiczny," EK 10, col. 956.

${ }^{26}$ Cf. FT, sec. 163.

27 Cf. M. Urban, "Indywidualizm - kolektywizm a ideologie polityczne," Studia Politologiczne 17, p. 162.

${ }_{28}$ Cf. R. Tokarczyk, Współczesne doktryny, p. 65.

${ }^{29}$ Cf. M. Urban, "Indywidualizm," p. 163.

30 Cf. R. Tokarczyk, Wspótczesne doktryny, p. 67.

31 Cf. M. Urban, “Indywidualizm,” p. 163.

${ }^{32}$ FT, sec. 165. 
forms of dogmatization in the selective actions of the state. ${ }^{33}$ If that is the case, significant areas of society become excluded from the care provided by the institutions, and the tools being used quickly become completely unfit for the purpose of effectively counteracting the problems faced by the population. ${ }^{34}$ As a results of their lack of realism, individualized policies thus provide no assurance of being able to hold the instruments of power in the long run. ${ }^{35}$ In the opinion of Pope Francis, political individualism may apply to both individuals and groups, which means that it exists in both liberalism and socialism as systems which manifest themselves in modern-day social processes. ${ }^{36}$ Liberalism as an ideology has a direct impact on economic activity. In his analysis of the way in which the free-market economy operates, Pope Francis distances himself from the view that economic processes govern themselves as part of the supply-demand relationship. ${ }^{37}$ Speculation by economic agents leads to new or deepens the existing crises while at the same time successively undermining the trust necessary in economic exchange. ${ }^{38}$ In this manner, there emerges a widespread sense - or even physical experience - of injustice that is attributed to the manner in which the state operates as a whole, and this in turn may give rise to a sense of helplessness. ${ }^{39}$ Populism and liberalism appeal directly to specific traits of the human nature, which is why populists and liberals can relatively quickly gather large groups of supporters around them. ${ }^{40}$ Political activities pursued by using selective coordinates in fact deepen the crisis, or at best stifle the development ${ }^{41}$ that corresponds to the principle of the common good. ${ }^{42}$

${ }^{33}$ Cf. I. Mroczkowski, "Liberalizm," col. 956.

${ }^{34}$ Cf. FT, sec. 165.

35 Cf. Francis, General Audience of 11 September 2019, https://www.vatican.va/ content/francesco/en/audiences/2019/documents/papa-francesco_20190911_udienzagenerale.html.

${ }^{36}$ Cf. FT, sec. 165.

37 Cf. ibid., sec. 168.

38 Cf. $C V$, sec. 21.

39 Cf. I. Mroczkowski, “Liberalizm,” col. 956.

40 Cf. S. Olszyk, “Vox populi,” pp. 237-238.

${ }^{41}$ Cf. Francis, General Audience of 4 December 2019, https://www.vatican.va/ content/francesco/en/audiences/2019/documents/papa-francesco_20191204_udienzagenerale.html.

42 Cf. GS, sec. 26. 


\section{REALISM OF SOCIAL CHARITY}

Ideologies or social trends such as populism or liberalism (and, as previously noted, Marxism) can be overcome by grounding the political activities being pursued in realism as a fundamental criterion of action. ${ }^{43}$ This realism applies equally to the characteristics of social phenomena and to the effectiveness of political action aimed at restoring social equity ${ }^{44}$ In his argument for realism in political activity, Pope Francis distinguishes two aspects: the formal aspect and the substantive aspect. ${ }^{45}$ In the formal aspect, the fundamental issue is to restore an attitude of openness. ${ }^{46}$ More specifically, populism and liberalism entail a closing of political and economic systems that is guided by selfish interest ${ }^{47}$ or ruthless pursuit of profit. ${ }^{48}$ Therefore, the suggested attitude of openness is a precondition for dialogue as a form (or rather a means) of arriving at solutions to sensitive social issues in the modern-day environment in which there exists an inexplicable conglomeration of politics and economy. ${ }^{49} \mathrm{Ac}-$ cording to Pope Francis, "'what is needed is a politics which is far-sighted and capable of a new, integral and interdisciplinary approach to handling the different aspects of the crisis.' In other words, a 'healthy politics... capable of reforming and coordinating institutions, promoting best practices and overcoming undue pressure and bureaucratic inertia." ${ }^{50}$ An attitude of dialogue stands in opposition to any type of conduct that excludes individuals or social groups on account of the prevailing ideology (or selfish interest). ${ }^{51}$ The parties to the dialogue find a common ground and show their willingness to achieve a consensus that serves the interests of a given community and, at the same time, fosters individual develop-

${ }^{43}$ Cf. Francis, General Audience of 9 October 2019.

${ }^{44}$ Cf. John XXIII, Mater et magistra, encyclical letter, Vatican City 1961, secs. 70-71 (hereafter cited as MeM).

45 Cf. J. Szulist, Teologia państwa, pp. 53-54.

${ }^{46}$ Cf. FT, sec. 177.

47 Cf. ibid., sec. 160.

48 Cf. ibid., sec. 168.

49 Cf. ibid., sec. 173.

50 Ibid., sec. 177.

51 Cf. J. Szulist, Teologia państwa, p. 57. 
ment. ${ }^{52} \mathrm{~A}$ certain prerequisite for this dialogue is respect for the dignity of every human being, which confirms the uniqueness of every person in the world. ${ }^{53}$

In addition to its formal aspect, the realism of political activity also has a substantive aspect that directly concerns the common good. The Second Vatican Council invokes the notion of the "common good" as a principle centered on the person ${ }^{54}$ who - together with others - humanizes the world and thus expresses the idea of integral development. ${ }^{55}$ Despite its assumed universality, the general human progress retains freedom as an inviolable value in the individual and social dimensions. ${ }^{56} \mathrm{By}$ referring to the principle of the common good, Pope Francis points to the inextricable relationship between this principle and the principle of subsidiarity, a relationship which in essence favors development. As he notes, "underlying the principle of the common good is respect for the human person as such, endowed with basic and inalienable rights ordered to his or her integral development. It has also to do with the overall welfare of society and the development of a variety of intermediate groups, applying the principle of subsidiarity." ${ }^{57}$ Adherence to the principle of the common good in politics deepens the sense of social equity by referring to the fundamental criteria of any exchange: personal dignity and human rights. ${ }^{58}$ A true test of the extent to which the principle of the common good is being followed is how the state treats those most vulnerable, ${ }^{59}$ who often live below the administrative poverty line $e^{60}$ or - worse still - below the existential poverty line, with their health deteriorating due to the lack of the

${ }^{52}$ Cf. Francis, "Duch błogosławi gospodarce," L’Osservatore Romano (Polish edition) 2-3 (2020), p. 9.

${ }^{53}$ Cf. Pontifical Council for Justice and Peace, Compendium of the Social Doctrine of the Church, Washington 2005, sec. 133 (hereafter cited as CSDC).

${ }^{54}$ Cf. GS, sec. 26.

55 Cf. Paul VI, Populorum progressio, encyclical letter, Vatican City 1967, sec. 14 (hereafter cited as $P P$ ).

56 Cf. S. Fel, "Prawa człowieka - rozwój idei, podstawa, treść i ochrona," in: Katolicka nauka społeczna. Podstawowe zagadnienia z życia społecznego i politycznego, ed. S. Fel and J. Kupny, Katowice 2007, p. 63.

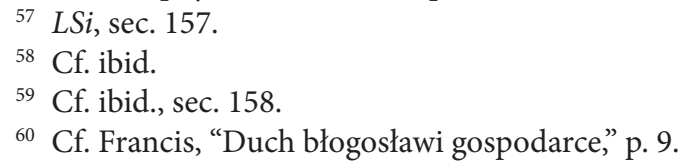


necessary means. ${ }^{61}$ The common good as a principle, however, not only determines the extent of the ad hoc interventions of the state, thus being consistent with the principle of subsidiarity (at least in terms of its impact), ${ }^{62}$ but also should be the subject of educational efforts in the sense of shaping a human being's personality from the earliest stages of his or her life. ${ }^{63}$ In this context, Pope Francis notes the importance of the family as the fundamental environment for a human being. ${ }^{64}$ In natural communities, a person internalizes the need to respect every human being as a precondition for development at any level - from the household to the international community. ${ }^{65}$ Politicians' concern for the family is therefore an expression of realism in their commitment to humanize the world ${ }^{66}$ while rationalizing the means, whereby the utility is determined by the good of a specific human person. ${ }^{67}$

The application of the principle of the common good in political activity culminates in social charity, ${ }^{68}$ which affects the manner in which the state operates in terms of the functioning of its institutions or - directly the conduct of the politicians, who actively engage in efforts to eliminate all forms of injustice. ${ }^{69}$ In this context, Pope Francis uses the notion of social friendship - a type of friendship characterized by openness and the ability to find appropriate ways to help one's neighbors. ${ }^{70}$ Social friendship is an expression of charity; it is, to some degree, equivalent to charity, as expressed by the pope in the following passage of his social encyclical Fratelli tutti: [block] This political charity is born of a social awareness that

${ }^{61}$ Cf. A. Pollok, "Metody analizy ekonomicznej zjawiska ubóstwa," Ruch Prawniczy, Ekonomiczny i Socjologiczny LXIV (2020) 4, p. 152.

${ }^{62}$ Cf. Francis, Angelus, 16 February 2020, https://www.vatican.va/content/francesco/en/angelus/2020/documents/papa-francesco_angelus_20200216.html.

${ }^{63}$ Cf. J. Szulist, W kierunku pełniejszego człowieczeństwa. Dobro wspólne jako wzorzec dla personalistycznych odniesień w rzeczywistości społeczno-politycznej, Pelplin 2009, p. 365.

${ }^{64}$ Cf. $L S i$, sec. 157.

${ }^{65}$ Cf. A. Fordoński, "Kategoria wspólnoty we współczesnej społecznej nauce Kościoła katolickiego," Dialogi Polityczne 14 (2011), p. 41.

${ }^{66}$ Cf. J. Szulist, Teologia państwa, p. 64.

${ }^{67}$ Cf. R. Brunelli, "Papieże i środowisko," L'Osservatore Romano (Polish edition) 11 (2019), p. 17.

${ }^{68}$ Cf. FT, sec. 180.

${ }^{69}$ Cf. Francis, "Duch błogosławi gospodarce," p. 9.

${ }^{70}$ Cf. FT, sec. 180. 
transcends every individualistic mindset: "'Social charity makes us love the common good,' it makes us effectively seek the good of all people, considered not only as individuals or private persons, but also in the social dimension that unites them." Each of us is fully a person when we are part of a people; at the same time, there are no peoples without respect for the individuality of each person. ${ }^{71}$ Social charity can be fulfilled in a society which is conscious of its own identity founded on mutual relations. ${ }^{72}$ Arguing for the communal character of these relations, Pope Francis points to the necessity of building peace, which exists wherever personal rights are the foundation of justice, solidarity, etc. ${ }^{73}$

The realism of social charity that should characterize political activity in Pope Francis's understanding essentially serves to express the personality of the individual as someone whose calling is to share to an ever greater extent in the eternal possessions. ${ }^{74} \mathrm{~A}$ human being as a certain whole participates in the salvific order. ${ }^{75}$ In the encyclical Fratelli tutti, one may identify two characteristics of individuals' political activities that free all forms of social engagement from mythical, ideological and other similar elements that undermine their realism. ${ }^{76}$ The first characteristic is the voluntary nature of acts done for the common good, especially with respect to the most vulnerable members of the society. ${ }^{77}$ A politician works within the framework of their electoral program or within the platform of the party which they represent or with which they identify. ${ }^{78}$ This framework, however, does not invalidate the reactions that stem from the sense of personal dignity and the natural concern for the dignified life of others.

71 Ibid., sec. 182.

72 Cf. Francis, Letter of His Holiness Pope Francis to the Popular Movements, https:// www.vatican.va/content/francesco/en/letters/2020/documents/papa-francesco_20200412_ lettera-movimentipopolari.html.

${ }^{73}$ Cf. FT, sec. 181.

${ }^{74}$ Cf. R. Brunelli, "Papieże i środowisko," p. 17.

75 Cf. Catechism of the Catholic Church, 2nd ed., Vatican City 1997, sec. 603 (hereafter cited as CCC). Francis, Address of his Holiness Pope Francis to Members of the International Theological Commission, https://www.vatican.va/content/francesco/en/ speeches/2019/november/documents/papa-francesco_20191129_commissione-teologica.html.

${ }^{76}$ Cf. FT, sec. 161.

77 Cf. ibid., sec. 186.

78 Cf. J. J. Wiatr, Socjologia polityki, p. 272. 
Pope Francis warns against an understanding of politics (or public activity in general) whereby each form of aid is perceived solely as a command, an externally imposed obligation. ${ }^{79}$ The lack of voluntariness - or, more appropriately, a personal, unforced willingness to help - considerably reduces the extent of real initiatives and solutions. ${ }^{80}$ The voluntary nature of politicians' actions improves their standing in the society in the sense of lasting approval of the politicians' efforts rather than momentary admiration that results from the propagation of populist slogans. ${ }^{81}$ The other characteristic of political activity that determines its realism is willingness to make sacrifices. ${ }^{82}$ In the philosophical tradition shaped to some degree by the Judeo-Christian account, attention is drawn to the unique character of the human person in the world. ${ }^{83}$ Specifically, this pertains to the suggestion raised by Immanuel Kant that one cannot put a price on a human life in the society. ${ }^{84}$ Therefore, a person cannot be reduced to an object of use, which would entail the appropriation of others - as is the case with other things in the manufacturing process, the cultural message, etc. ${ }^{85}$

\section{CONCLUSION}

The doctrine of the Church considers politics to be a form of service to the citizens that aims to promote integral development in the individual and social dimensions. As Pope Francis has noted, however, a drawback of the contemporary political communities is the illusory nature of the actions taken by the governments that favor, at most, selfish or partisan interests. Sustained bidirectional communication between those

${ }^{79}$ Cf. FT, sec. 186.

${ }^{80}$ Cf. Francis, Angelus.

81 Cf. FT, sec. 186.

82 Cf. ibid., sec. 187.

${ }^{83}$ Cf. Francis, Video Message of his Holiness Pope Francis to Mark the Holy Week 2020, https://www.vatican.va/content/francesco/en/messages/pont-messages/2020/documents/papa-francesco_20200403_videomessaggio-settimanasanta.html.

${ }^{84}$ Cf. J. Miklaszewska, "Godność człowieka w koncepcji Immanuela Kanta a doświadczenie Auschwitz," Ruch Filozoficzny LXXII (2017) 4, pp. 48-49.

85 Cf. Francis, Letter of His Holiness Pope Francis to the Popular Movements. 
in power and the citizens simply does not exist in the long run. On the basis of the teachings of the encyclical Fratelli tutti, two trends can be identified that together express the mythicalness of today's politics. The first of these trends is populism, whose rationale is to take advantage of temporary public support to pursue selfish interests of politicians or political parties. Populists cater to the lowest instincts, antagonizing social groups in the process. Such politicians have a narrow focus on immediate benefits, completely ignoring the long-term development of social attitudes. The second trend is liberalism. While the universally proclaimed freedom on account of which economic activity takes place gives the richest a sense of autonomy, vulnerable social groups that do not directly participate in economic development are marginalized to an even greater degree. In this manner, the sense of social injustice is deepened as there is virtually no support from politicians, who are only preoccupied with retaining power. To overcome the above negative, derealizing trends, it is necessary for politicians to recognize the need to fulfill the demands of the common good that determine the development of each individual citizen and the society at large. In his definition of the common good, Pope Francis draws directly from his encyclical letter Laudato si, which in turn makes direct references to the Pastoral Constitution on the Church in the Modern World: Gaudium et Spes. Commitment to the fulfillment of the common good is made on the basis of social charity, which integrates citizens and, at the same time, mobilizes them to humanize the world.

\section{BIBLIOGRAPHY}

Benedict XVI, Deus caritas est, encyclical letter, Vatican City 2005.

Benedict XVI, Caritas in veritate, encyclical letter, Vatican City 2009.

Brunelli R., "Papieże i środowisko," L'Osservatore Romano (Polish edition) 11 (2019), pp. 14-17.

Bużyk M. M., "Problematyka filozoficznych podstaw pedagogiki w sporze Wydziału Filozofii Chrześcijańskiej KUL z marksizmem," Polska Myśl Pedagogiczna 3 (2017), pp. 63-80.

Catechism of the Catholic Church, 2nd ed., Vatican City 1997.

Fel S., "Prawa człowieka - rozwój idei, podstawa, treść i ochrona," in: Katolicka nauka społeczna. Podstawowe zagadnienia z życia społecznego i politycznego, ed. S. Fel and J. Kupny, Katowice 2007, pp. 57-75. 
Fordoński A., "Kategoria wspólnoty we współczesnej społecznej nauce Kościoła katolickiego," Dialogi Polityczne 14 (2011), pp. 31-46.

Francis, "Duch błogosławi gospodarce," L'Osservatore Romano (Polish edition) 2-3 (2020), pp. 8-9.

Francis, Address of his Holiness Pope Francis to Members of the International Theological Commission, https://www.vatican.va/content/francesco/en/speeches/2019/ november/documents/papa-francesco_20191129_commissione-teologica.html.

Francis, Angelus, 16 February 2020, https://www.vatican.va/content/francesco/en/angelus/2020/documents/papa-francesco_angelus_20200216.html.

Francis, Fratelli tutti, encyclical letter, Vatican City 2020.

Francis, General Audience of 11 September 2019, https://www.vatican.va/content/francesco/ en/audiences/2019/documents/papa-francesco_20190911_udienza-generale.html.

Francis, General Audience of 4 December 2019, https:/www.vatican.va/content/francesco/ en/audiences/2019/documents/papa-francesco_20191204_udienza-generale.html.

Francis, General Audience of 9 October 2019, https:/www.vatican.va/content/francesco/ en/audiences/2019/documents/papa-francesco_20191009_udienza-generale.html.

Francis, Laudato si, encyclical letter, Vatican City 2015.

Francis, Letter of His Holiness Pope Francis to the Popular Movements, https://www.vatican.

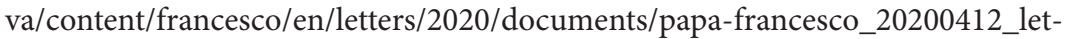
tera-movimentipopolari.html.

Francis, Video Message of his Holiness Pope Francis to Mark the Holy Week 2020, https://www.vatican.va/content/francesco/en/messages/pont-messages/2020/documents/papa-francesco_20200403_videomessaggio-settimanasanta.html.

John Paul II, Laborem exercens, encyclical letter, Vatican City 1981.

John XXIII, Mater et magistra, encyclical letter, Vatican City 1961.

Miklaszewska J., “Godność człowieka w koncepcji Immanuela Kanta a doświadczenie Auschwitz," Ruch Filozoficzny LXXII (2017) 4, pp. 47-64.

Mroczkowski I., "Liberalizm. Aspekt teologiczny," EK 10, cols. 956-957.

Olszyk S., "Vox populi, vox Dei': teoria populizmu politycznego," Annales Universitatis Paedagogicae Cracoviensis. Studia Politologica 3 (2007), pp. 236-247.

Pakulski J., "Ruchy populistyczne i degeneracja elit przywódczych - analiza weberowska," Zoon Politiko 7 (2016), pp. 56-74.

Paul VI, Populorum progressio, encyclical letter, Vatican City 1967.

Pinckaers S. T., Źródła moralności chrześcijańskiej, Poznań 1994.

Pollok A., "Metody analizy ekonomicznej zjawiska ubóstwa," Ruch Prawniczy, Ekonomiczny i Socjologiczny LXIV (2020) 4, pp. 149-171.

Pontifical Council for Justice and Peace, Compendium of the Social Doctrine of the Church, Washington 2005.

Potulski J., "Problem 'tego co polityczne’ a tożsamość badawcza politologii," Annales Universitatis Mariae Curie-Skłodowska XXIII (2016) 2, pp. 61-81.

Second Vatican Council, Pastoral Constitution on the Church in the Modern World: Gaudium et spes, Vatican City 1965.

Szulist J., "Człowiek jest droga Kościoła" (RH 14). Wprowadzenie do katolickiej nauki społecznej, Pelplin 2012. 
Szulist J., Teologia państwa w pismach Josepha Ratzingera (Benedykta XVI), Toruń 2016.

Szulist J., W kierunku pełniejszego człowieczeństwa. Dobro wspólne jako wzorzec dla personalistycznych odniesień w rzeczywistości społeczno-politycznej, Pelplin 2009.

Tokarczyk R., Współczesne doktryny polityczne, Warsaw 2010.

Urban M., "Indywidualizm - kolektywizm a ideologie polityczne," Studia Politologiczne 17 , pp. $160-171$.

Wiatr J. J., Socjologia polityki, Warsaw 2009. 